\title{
The doctrines of original sin and the virgin birth: divine revelation or human construct?
}

I J J Spangenberg

(University of South Africa)

\section{ABSTRACT \\ The doctrines of original sin and the virgin birth: divine revelation or human construct?}

Two South African theologians, Ben du Toit and Anton van Niekerk, recently published books in which they argued that postmodern believers can no longer subscribe to the doctrines of original sin and the virgin birth. According to them both these doctrines reflect a premodern world-view which should be regarded as outdated. However, they would not like to take leave of the grand narrative of Christianity. There are some fundamental flaws in the reasoning of both scholars. The doctrine of the virgin birth is intertwined with the doctrine of original sin, and both are important to the orthodox doctrine of salvation. As it is not viable or consistent to tamper with some of the orthodox doctrines and try to keep the rest intact, we are left with two options, either to discard the whole system and start afresh, or to try and keep the whole package intact. However, biblical research since the Enlightenment has ruled out the second option. The paper argues in support of this case and attempts to offer a different way forward for Christians living in the twenty-first century than the one offered by Du Toit and Van Niekerk.

\section{INTRODUCTION}

Eight years ago, the South African theologian Ben du Toit published his book God? Belief in a postmodern era ${ }^{1}$ Well received in some theological circles, it was awarded the Andrew Murray Prize for the best theological work published that year (Spangenberg 2003:8486). Du Toit argues that postmodern believers can no longer subscribe to doctrines that reflect the pre-modern world-view. He describes at length how the European world-view has changed since the Enlightenment, and assesses the consequent impact of this change on the Christian belief system and doctrines (Du Toit 2000:7-61).

1 My Afrikaans translation of the title: God? Geloof in 'n postmoderne tyd (2000). 
I read this book with appreciation, but found it difficult to understand Du Toit's willingness to sacrifice some of the traditional Christian doctrines, such as the virgin birth and the resurrection, while vehemently defending others. Du Toit takes leave of the doctrine of the virgin birth with ease, proclaiming that: "Jesus' work as Saviour is not founded on the virgin birth but upon the crucifixion and resurrection". writes: "First, the resurrection of Jesus is the fulcrum of the Christian belief, since Jesus is held to be the Saviour of the world. If the resurrection is not historically true then Christianity has no message to proclaim"3.

In his book Belief without absolutes: Reflections for contemporary believers ${ }^{4}$, Anton van Niekerk, a philosopher at the University of Stellenbosch, argues along similar lines. In the opening chapter, Van Niekerk expresses some reservations about the doctrines of original sin and the virgin birth, writing that church leaders can no longer expect ordinary church members to adhere to these outdated doctrines. However, a few pages later, he states: "Although I am critical about the Christian doctrines of 'original sin' and the 'virgin birth' I do not want to get rid of the baby with the bath-water". The "baby" is evidently the doctrine that Jesus is the Saviour of the world.

There are some fundamental flaws in the reasoning of both scholars. The doctrine of the virgin birth is intertwined with the doctrine of original sin, and both are important to the orthodox doctrine of salvation. Neil Ormerod (1992:6) formulates this as follows:

2 The original Afrikaans reads: "Jesus se verlossingswerk berus nie op die maagdelike geboorte nie, maar op sy kruisdood en opstanding" (Du Toit 2000:148).

3 The original Afrikaans rendering reads: "Eerstens behoort die opstanding van Jesus tot die kern van die boodskap van die Christendom, waarin Hy as die Verlosser van die wêreld voorgestel word. Indien dit histories nie waar is nie, sou die Christendom eintlik nie 'n boodskap hê nie" (Du Toit 2000:150).

4 My Afrikaans translation of the title: Geloof sonder sekerhede: Besinning vir eietydse gelowiges (2005).

5 The original Afrikaans reads: "Dat ek krities is oor die kerklike leer oor die 'erfsonde' en die 'maagdelike geboorte van Christus' beteken natuurlik nie dat ek die baba met die badwater wil weggooi nie" (Van Niekerk 2005:19). 
The doctrine of original sin does not stand in some splendid theological isolation in the Christian view of the world. Indeed it stands in profound relationship to theologies of grace and redemption. To reject the doctrine of original sin would be to call into question much of Christian faith and theology.

He correctly argues that one cannot discard the doctrine of original sin and still proclaim that Jesus is the Saviour of the world. The one doctrine is the basis of the other.

Raymond Brown (1999:598) also recognises this when he writes: "That Jesus was asexually conceived explains how he was free of original sin - a connection made even in our times in a more sophisticated manner by Karl Barth."

According to the doctrine of original sin, if Jesus had been conceived like any other human being, He would, like any other human being, have inherited a "tainted" nature. He would therefore have been unable to act as the Saviour of humanity. Zacharias Ursinus and Caspar Olevianus formulated this theological idea in the following manner in the Heidelberg Catechism, Lord's Day 14:

Question 35. What is the meaning of: "Conceived of the Holy Spirit, born of the Virgin Mary"?

That the eternal Son of God, who is and remains true and eternal God, took upon himself our true manhood from the flesh and blood of the Virgin Mary through the action of the Holy Spirit, so that he might also be the true seed of David, like his fellow men in all things, except for sin.

Question 36. What benefit do you have from the holy conception and birth of Christ?

That he is our Mediator, and that, in God's sight, he covers over with his innocence and perfect holiness the sinfulness in which I have been conceived.

(Pelikan \& Hotchkiss 2003:435-436)

As it is not viable or consistent to tamper with some of the orthodox doctrines but try to keep the rest intact, we are left with two options, either to discard the whole system and start afresh, or to try and keep the whole package intact. However, biblical research since the Enlightenment has ruled out the second option. The rest of my paper 
will argue in support of this case and will attempt to offer a different way forward for Christians living in the twenty-first century than the one offered by Ben du Toit and Anton van Niekerk.

\section{THE DOCTRINE OF ORIGINAL SIN}

Augustine (354-430), one of the Latin fathers of the Church, was the main architect of the doctrine of original $\sin ^{6}$. He advocated the view that Adam was created immortal and could have lived forever had he and Eve not disobeyed the command not to eat from the tree standing in the middle of the garden (Gn 2:9, 16-17). The "fall", as is known, affects every human being born after Adam and Eve. Geoffrey Lampe (2003:162) summarises Augustine's view as follows:
All Adam's progeny has been contaminated by Adam's sin, not by voluntarily following his example but by being in Adam "as in a root"; it [Adam's progeny] is therefore under the divine sentence of death and damnation, doomed to carry its burden of original sin to the appointed end which is eternal punishment with the rebellious angels.

Augustine believed that original sin was transmitted from one generation to the next by means of sexual intercourse. Sexual desire precedes sexual intercourse, and the desire itself reflects our fallen condition, since humans cannot control that desire. As Lampe (2003:162) points out, "Augustine always regards sexual desire as irrational and a token of man's fallen condition."

Pelagius and his disciple Celestius opposed Augustine's views. Pelagius argued that although Adam committed the primal transgression, his guilt was not passed on to other generations. Human beings are not intrinsically evil, but are capable of choosing good over evil. Celestius argued that "Adam was created mortal, and

6 Timothy Sisemore (2004:222) is but one of a number of scholars who acknowledges this: "Augustine was the one who codified the ideas before him into a systematic understanding of original sin." Herman Wiersinga (1992:42) goes even further and claims that the whole of Western theological tradition can be traced back to the theology of Augustine: "Augustinus (354-430), kan als grondlegger van de westerse theologie getypeerd worden. Zijn bijnaam werd 'leraar van de genade', maar je zou hem evengoed 'leraar van de sonde' kunnen noemen." 
would have died whether or not he sinned; his sin injured himself alone and not the entire human race" (Lampe 2003:161).

Julian of Eclanum concurred with Pelagius's views, maintaining that Augustine's denigration of sexual desire and intercourse should be ascribed to Manichaean influence during his earlier years ${ }^{7}$. The Emperor Honorius was eventually forced to intervene to settle the differences between the two groups, as they had started to undermine the social order in Rome. He condemned Pelagius and his followers and banned them from Rome in $418 \mathrm{CE}$. However, it was only at the Council of Ephesus in $431 \mathrm{CE}$ that Pelagianism (as the view of Pelagius and his followers had come to be known) was finally condemned. Augustine's views triumphed and became the official doctrine of Western Christianity (Freeman 2003:298-299).

The following biblical texts are usually quoted when the doctrine of original sin is discussed: Genesis 2-3, Psalm 51:7 and Romans 5:12-21. Augustine himself claimed that these passages affirmed his ideas. However, critical study of the Bible over the past three centuries has revealed that Pelagius, Celestius and Julian of Eclanum had a far better understanding of these texts and of how sin is viewed and described in the Old Testament. A short discussion of these texts will clarify this.

\subsection{Genesis 2-3}

Previously, Christian theologians regarded Genesis $1-3$ as a single creation story comprised of two episodes. The first episode was seen as a narration of how a perfect creation came into being (Gn 1), while the second told how this perfect creation was destroyed (Gn 23 ). Some theologians argued that the "fall of the angels" occurred between the two episodes (Bavinck 1932:98). Old Testament scholars now agree that Genesis 1-3 is comprised of two different stories, the P- and the J-narratives, and that neither of them is a historical account of what happened at the start of creation (Westermann 1972:13, 26-27).

7 The following comment by Jacob Slavenburg (1995:131) may be linked to the verdict of Julian of Eclanum: "De obsessie van Augustinus voor de seksualiteit en zijn gevecht tegen de lust waren wellicht een reactie op zijn eigen seksueel zeer roerige jeugd. De op leeftijd gekomen kerkvader verbond deze menslijke kracht direct met de erfzonde". 
The boundaries of the first creation story are defined as Genesis 1:1-2:4a, while those of the second are Genesis 2:4b-3:24. The first story concludes with the words: "Such is the story of heaven and earth when they were created" (Gn 2:4a). The second begins with the words: "When the LORD God made earth and heaven...." (Gn 2:4b). A discerning reader will immediately recognise that the words "heaven and earth" in the first narrative are reversed in the second, to read "earth and heaven".

These stories originated in different contexts and conveyed different messages to their first readers. The first story (Gn 1:1-2:4a) tells how the whole cosmos was created in six days, the seventh being the most important, because the LORD Himself rested on that day. This creation story probably originated in Babylonia during the exile, being told primarily to recount the origin of the Sabbath and to legitimise its celebration. By keeping this festival, the Judeans affirmed their identity in a foreign country.

The second creation story (Gn 2:4b-3:24) explains why human beings possess divine knowledge, but not divine life. That means they are able to distinguish between good and evil, but they do not live forever. According to the story, a male human being is created to till the soil (Gn 2:4b-5). He is a co-creator, but mortal, being created from the soil of the earth (Gn 2:7). Nothing in the narrative suggests that he was created immortal, as Augustine and other theologians would like us to believe (Von Rad 1976:95; Barr 1992:21). Later in the story, a female human being is created as a companion for Adam. Instigated by the serpent, this companion eats from the forbidden tree and gives some of the fruit to her male companion (Gn 3:1-6). The serpent is not the devil, or the villain of the story, as the authors of some of the biblical books would have us believe. In fact, he helps the human beings attain divine knowledge.

When the LORD God arrives on the scene, He has to deal with an unexpected situation (Gn 3:8-11). The human beings suddenly possess divine knowledge! However, He does not react as if his eternal plans have been frustrated by the actions of the two human beings. On the contrary, He enquires about the source of their awareness that they were naked (Gn 3:11). After getting to the root of the matter, He makes the characters pay individually for their acquisition. Divine knowledge comes at a price. Because he offered the fruit, the serpent will be forced to crawl on the surface of the 
earth for the rest of his life. Moreover, there will be enmity between him and the woman; between his progeny and hers (Gn 3:14-15). Why? It might be because serpents shed their skins, creating the impression that they possess divine life, which human beings could have gained by eating from the tree of life. Human beings are envious of serpents for their ability to regenerate themselves, which human beings cannot do.

The woman is obliged to pay the price for acquiring divine knowledge by suffering the pangs of childbirth and being subservient to her husband (Gn 3:16). The male pays the price of having to work hard to eke out a living (Gn 3:17-19). However, the price does not include death! The narrator states merely that the male human being will pay the price until death (Gn 3:19).

How else can this interpretation be corroborated? First, this narrative is a story, not history. A real Adam and Eve never existed. They and the serpent are characters in a story. Even the LORD God is a character in the narrative, dependent on the will of the narrator. Moreover, the Hebrew word for "sin" does not appear anywhere in the story (Tucker 1978:119; Primavesi 2000:30). Furthermore, none of the other biblical books ever refer to this story to explain the origin of sin and mortality. Informed contemporary humans know that death is a natural phenomenon from which they are not exempt (Eloff 1975:15; Primavesi 1991:228; Weber 1998:106). The ancient Israelites shared this realistic view of life and death, holding that death was "unnatural" only when it struck before someone had lived a full life (Smelik 2003:26).

Augustine's interpretation of Genesis $2-3$ is inaccurate. His error lay in reading the narrative as the historical account of a "fall" at the dawn of creation. However, he was influenced by Ambrosiaster's reading of Romans 5:12, and therefore misunderstood Paul's comments. Moreover, he associated "original sin" with sexual desire, thereby degrading human sexuality. The two human beings in Genesis 2-3 were not a-sexual before they ate the fruit. The narrator does not suggest that "knowing good and bad" should be linked to "the knowledge or consciousness of sexuality" (Rosenberg \& Bloom 1990:183).

Not only were Augustine's theological ideas inaccurate, but they had a negative influence on the way in which Europeans viewed themselves and people of other cultures. Moreover, these views 
contributed to the denigration of women in the church and in Western society (Benjamin 1997:50).

\subsection{Psalm 51:7}

The second text usually cited in support of the doctrine of original sin is Psalm 51:7 (Bosman 1983:264-271), one of seven so-called "penitential psalms" (Ps 6, 32, 38, 51, 102, 130, 143). This designation is not indicative of the genre of these psalms but of their use in Christian worship. In the Christian tradition, "[t]hese psalms [lead] supplicants through confession of $\sin$ to forgiveness, and beyond that to renewed praise of God" (Crenshaw 2001:57). However, this is not the primary intention of the psalm. Psalm 51 belongs to the genre of "personal laments", in which a poet complains about an ordeal he has undergone, or a life-threatening event he has faced. He addresses God, requesting his assistance.

The heading of this psalm creates the impression that David composed it when the prophet Nathan called him to account for his misconduct after he acknowledged that he had committed adultery. However, the psalm contains no clues that point to this life-setting, and research has revealed that the headings were added at a later stage (Gillingham 1994: 246-247; Seybold 1997:34-58). For this reason, the numbering of the verses in more recent Bible translations may differ from that in older versions. Some current translations commence with the numbering of the verses only after the headings.

According to Jan Fokkelman (2001:122; 2002:61), Psalm 51 can be divided into nine strophes: verses $3-5,6,7-8,9-11,12-13$, 14-15, 16-17, 18-19, 20-21. Verses 12-13 are the focal point of the psalm since "there are two pairs of strophes before and after the center" (Fokkelman 2001:122). In these verses, the poet implores God to create in him a pure heart and a steadfast spirit, and not to cast the poet away from his presence.

In the background of these psalms lies the well-known Israelite credo, which reads: "The LORD is compassionate and gracious, long-suffering and ever faithful." This credo is found in each of the three main sections of the Hebrew Bible — the Pentateuch (Ex 34:6), the Prophets (Jonah 4:2) and the Writings (Ps 103:8). This may serve as an indication of how important it became after the exile. In Psalm 51, an anonymous poet recalls God's gracious love and mercy while reflecting on his own misdeeds and consequent predicament. The words "be gracious", "your faithful love", and "the 
fullness of your mercy" in the opening verse of the psalm (v 3) give evidence of this.

Verses 7 and 8 form the third strophe, a couplet. The poet uses a hyperbole in the first line of this couplet to describe his own unworthiness: "From my birth I have been evil, sinful from the time my mother conceived me" ( $\mathrm{v} 7)^{8}$. The next poetic line (v 8) provides a contrast, when the poet reflects on what is desirable to God, which is "faithfulness in the inmost being" (v 8a). However, this could be achieved only if God were to step in and teach him wisdom. This is expressed in the supplication: "teach me wisdom in my heart" ( $\mathrm{v}$ $8 \mathrm{~b}$ ). The poet is not describing the "universal human predicament", as Christian theologians since Augustine have claimed, but is requesting wisdom for guidance. The emphasis falls on the contents of verse 8 , not on those of verse 7 .

Augustine understandably found support for his ideas on original sin in this verse, but the fact is that he did not possess the knowledge of Hebrew poetry, psalm genres and poetic devices that we have today. He simply did not know that this psalm is an individual lament and that the individual psalms, the thanksgivings, and the wisdom psalms emphasise integrity of the heart, inner piety and trust, social concern, and ethical obedience (Gillingham 1994:271). Moreover, the hyperbole in verse 7 completely escaped his attention. Lastly, the reference to the broken walls of Jerusalem (v 20) reflects a date after 587 BCE, which Augustine also ignored. If he had had the correct knowledge of the Hebrew language and could have read the Hebrew Bible, he might very well not have used Psalm 51:7 in his arguments. His theological arguments were based primarily on the Latin translation of the Bible, which was undoubtedly influenced by the preceding theological tradition.

\subsection{Romans 5:12-21}

This is the third text usually referred to when the doctrine of original sin is discussed. Theologians regard Romans 5:12-21 as the locus classicus for this doctrine (cf Durand 1978:127). However, critical

8 As has been mentioned, some Bible translations do not number the headings and the introductory statements. This means that the numbering of the verses may differ. In some translations, verses 7 and 8 are consequently numbered 5 and 6. 
interpretation of this section of the letter to the Romans leads to conclusions other than those advocated by Augustine.

Romans 5:12-21 is part of a larger section of the letter. A number of scholars identify the borders of this section as Romans 5:1 and 8:39 (cf Käsemann 1974:121; Ehrman 2008:366). It consists of the following seven sub-sections, which can be arranged to form a concentric structure:
A Romans 5:1-11
Saved from God's punishment at the final judgment
B Romans 5:12-21 The first Adam versus the second Adam
C Romans 6:1-13 United with Christ's death through baptism

\section{Romans 6:14-23 Sin as a cosmic force}

$\mathrm{C}^{1}$ Romans 7:1-25 The new dispensation versus the old

$\mathrm{B}^{1}$ Romans 8:1-17 The law of the spirit versus the law of sin and death

$\mathrm{A}^{1} \quad$ Romans 8:18-39 The end times bring the final renewal.

Antitheses are prominent in all the sub-sections except for the first (A) and the last $\left(\mathrm{A}^{1}\right)$. In these two sections, which may be classified as the introduction and conclusion of the argument, the issues of suffering, hope, the spirit and God's judgement receive particular attention. It is evident that Paul's apocalyptic idea of an end judgement forms the context for the antitheses formulated in the other sub-sections. According to Paul, God will judge all human beings during the end times except those who "have been justified through faith" $(\mathrm{Rm} 5: 1,9)$. These are "reconciled to God through the death of his Son" (Rm 5:10). Life may still be characterised by pain, suffering and hardship, but those who have accepted God's gift of righteousness have received the spirit as "the first fruits of the harvest to come" (Rm 8:23). The spirit supports and guides the believers ( $\mathrm{Rm} \mathrm{8:26)}$ in this life. But this is not all. Jesus is sitting at

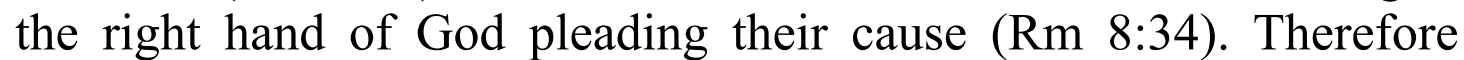
nothing in heaven and earth can separate them from the love of God, either now, or during the end times (Rm 8:38-39).

The second sub-section $(\mathrm{B})$ and the penultimate one $\left(\mathrm{B}^{1}\right)$ are similarly related. Both concern two dispensations. The second sub- 
section (B) describes the old dispensation as one dominated by the transgression of the first Adam and death. However, the new dispensation is dominated by the gift of righteousness and life, thanks to the second Adam ( $\mathrm{Rm}$ 5:17). The penultimate sub-section (B1) describes the old dispensation as one in which the "law of $\sin$ and death" ruled, while the new dispensation is characterised by the "law of the spirit" (Rm 8:2), which enables life.

In the third sub-section (C), sin, death and resurrection are prominent. It is through baptism that one participates in the death and resurrection of Jesus ( $\mathrm{Rm} \mathrm{6:4).} \mathrm{This} \mathrm{idea} \mathrm{is} \mathrm{extended} \mathrm{in} \mathrm{the} \mathrm{third}$ last sub-section $\left(\mathrm{C}^{1}\right)$. It is through the law that sin is made manifest. However, as soon as this happens, it becomes a monster that kills. "The commandment which should have led to life proved in my experience to lead to death, because in the commandment sin found its opportunity to seduce me, and through the commandment killed me" ( $\mathrm{Rm} 7: 10-11)$. However, it is by dying with Christ that one is freed from the law and escapes the influence of $\sin (\mathrm{Rm} 7: 4,6)$ :

So too, my friends, through the body of Christ you died to the law and were set free to give yourselves to another, to him who rose from the dead so that we may bear fruit for God ... But now, having died to that which held us bound, we are released from the law, to serve God in a new way, the way of the spirit in contrast to the old way of a written code.

(Revised English Bible 1989)

The centre-piece (D) contains the key to the whole section. Sin is a cosmic force which gained entrance into the world through the disobedience of the first Adam. However, this cosmic force has been broken, thanks to the crucifixion of Jesus: "When He died, He died to sin, once and for all, and now that He lives, He lives to God" (Rm 6:10). This being the case, all believers should regard themselves "as dead to sin and alive to God, in union with Christ Jesus" (Rm 6:11).

This short exposition should make it evident that Paul's focus is more on what God did in Jesus rather than on Adam's act and its effect on his progeny. This becomes particularly clear when Romans $5: 15-17$ is read closely:

But God's act of grace is out of proportion to Adam's wrongdoing. For if the wrongdoing of that one man 
brought death upon so many, its effect is vastly exceeded by the grace of God and the gift that came to so many by the grace of the one man, Jesus Christ. And again, the gift of God is not to be compared in its effect with that one man's sin; for the judicial action, following on the one offence, resulted in a verdict of condemnation, but the act of grace, following on so many misdeeds, resulted in a verdict of acquittal. If, by the wrongdoing of one man, death established its reign through that one man, much more shall those who in far greater measure receive grace and the gift of righteousness live and reign through the one man, Jesus Christ.

(Revised English Bible 1989)

Ambrosiaster's exegetical comments on Romans 5:12 influenced Augustine's reflections on $\sin ^{9}$. Recent Bible translators render the verse as: "Well then; it was through one man that sin came into the world, and through sin death, and thus death spread through the whole human race because everyone has sinned" (New Jerusalem Bible 1985). However, the Latin translation used by Ambrosiaster gave the last phrase as "in whom all have sinned" (in quo omnes peccaverunt). This led him to conclude that all human beings had sinned with Adam (cf Durand 1978:49). Augustine followed Ambrosiaster's lead and reasoned that if this were so they were a "condemned lump" who were therefore in need of a saviour. An erroneous translation thus gave support to a dubious theological doctrine that is not in the least aligned with Paul's arguments in Romans 5:1-8:39, as argued above.

Paul tried to convince the believers in Rome that the death of Jesus was an important event which had broken the force of sin. A new force had been introduced into the cosmos, "the force of the cross". Being baptised enabled one to tap into the power of this force.

The old and the new dispensations and what they entailed, according to Paul's reasoning in this section of the letter to the Romans, may be presented as follows:

9 Ambrosiaster is a pseudonymous theologian who lived in the fourth century CE. He was probably a contemporary of Ambrose (339-397) and Augustine (354-430). 


\begin{tabular}{|l|r|}
\hline \multicolumn{2}{|c|}{$\begin{array}{c}\text { Crucifixion } \\
\text { Baptism }\end{array}$} \\
\hline Old humanity & The way of the spirit \\
\hline Sinful nature & New humanity \\
\hline Slaves of sin & Slaves of righteousness \\
\hline First Adam & Second Adam \\
\hline Sin & \\
\hline Death & Lighteousness \\
\hline
\end{tabular}

\subsection{The doctrine of original $\sin =$ human construct}

We may conclude from the above arguments that Genesis 2:4b-3:24 is not a narrative about original sin and death as punishment; nor is David bewailing his "fallen nature" in Psalm 51:7, or Paul arguing a case in Romans 5:12-21 that Jesus could act as Saviour because $\mathrm{He}$ was born without original sin. Although there are theologians who continue to argue a case for original $\sin$ as if it were a "biblical doctrine" (Theron 2005:576-586), increasingly more biblical scholars are arguing that it is nowhere to be found in scripture. James Barr may serve as an example, and his comments on this issue are worth quoting in detail:

The thought that all death, at all times and in all circumstances, is due to a primeval fault is difficult to take seriously, and all the more so when we perceive that Old Testament scripture by no means supports this idea. Similarly, the belief that God really, on the ground of a fault committed by two humans in the beginning of the world, ordained death as a destiny for all later humanity, throughout history, has truly staggering effects on the idea of God. 
Now modern Old Testament scholarship has, I think, been agreed that the Pauline use of the story (we should call it a use rather than an interpretation) does not fit the actualities of the text. In that sense, even if Brunner may have brushed aside Köhler's judgement in 1926, competent scholarship has continued to conclude that, at least on the negative side, Köhler was right. The story of Adam and Eve was not the story of the "Fall of Man" in the traditional sense.

(Barr 1992:90-91)

\section{THE DOCTRINE OF THE VIRGIN BIRTH}

Before discussing the texts usually referred to when the virgin birth ("virgin conception" is better) of Jesus is discussed, it is important to look once again at why theologians deemed it important to argue a case for the virgin birth. As stated earlier, the main reason behind this doctrine is to present Jesus as a human being without blemish or sin. Had Jesus been conceived in the normal way, He would have shared in the "fall" and thus would not have been able to act as Saviour of humanity. In the Canons of the Synod of Dordt (16181619), in the section concerning the third and fourth main points of doctrine, it is stated:

Man brought forth children of the same nature as himself after the fall. That is to say, being corrupt he brought forth corrupt children. The corruption spread, by God's just judgement, from Adam to all his descendants except for Christ alone - not by way of imitation (as in former times the Pelagians would have it) but by way of the propagation of his perverted nature.

(Pelikan \& Hotchkiss 2003:584)

Jesus is exempt from the "fall" because He was conceived while Mary was still a virgin, so no man had impregnated her. Augustine even argued that Mary did not have an iota of sexual desire when Jesus was conceived, so she also gave birth without any pangs (Slavenburg 1995:131).

The doctrine that Jesus was conceived by a virgin is based on the infancy narratives of Matthew 1:18-25 and Luke 1:26-38. A short discussion of these sections from the two gospels will reveal that the authors were influenced by Old Testament narratives. 
Moreover, unlike later Christian theologians, they did not link their stories to the second creation narrative (Gn 2-3) and a so-called "fall".

\subsection{Matthew 1:18-25}

Matthew 1:18-25 should not be separated from the genealogy in Matthew 1:1-17. The birth story (Mt 1:18-25) is closely related to the genealogy and is a continuation of that section. It will soon become evident that its meaning is intertwined with the genealogy.

It is well-known that Matthew's birth narratives are interspersed with quotations from and allusions to the Old Testament. Matthew 1:18-25 commences with a phrase reminiscent of Genesis: "This is how Jesus came to be born" (Mt 1:18). The phrase can be translated as "This is the toledot (or history) of Jesus". The book of Genesis contains ten toledot, five in the Primeval Story (Gn 1-11) and five in the Ancestral Story (Gn 12-50). These can be presented as follows (Bandstra 1995:106-107):

\begin{tabular}{|c|c|}
\hline \multicolumn{1}{|c|}{ Primeval story } & \multicolumn{1}{c|}{ Ancestral story } \\
\hline 1. Heavens and earth (Gn 2:4) & 1. Terah (Gn11:27) \\
\hline 2. Adam (Gn 5:1) & 2. Ishmael (Gn 25:12) \\
\hline 3. Noah (Gn 6:9) & 3. Isaac (Gn 25:19) \\
\hline 4. Shem, Ham, Japhet (Gn 10:1) & 4. Esau (Gn 36:1,9) \\
\hline 5. Shem (Gn 11:10) & 5. Jacob (Gn 37:2) \\
\hline
\end{tabular}

Interestingly, although the tenth toledot in Genesis contains the Joseph narrative (Gn 37-50), it is called the toledot of Jacob (Gn 37:2). This is relevant if we are to understand Matthew's genealogy of Jesus.

Two people bear the name "Jacob" in the genealogy (Mt 1:117). The first is the patriarch Jacob (Mt 1:2), while the second is Jacob the grandfather of Jesus (Mt 1:15-16). According to Luke's genealogy the name of Jesus' grandfather was Heli (Lk 3:23). I suspect that the author of the gospel according to Matthew deliberately named Jesus' grandfather Jacob. In doing so, he reminded his readers of the toledot of Jacob in Genesis. Just as 
Joseph is sidelined in this toledot, so is Joseph (the father of Jesus) sidelined in Jesus' toledot. In both instances, the focus falls on someone else. Matthew records the toledot of Jesus, not that of Joseph, in the same way that Genesis narrates the toledot of Jacob rather than that of Joseph.

One may even argue that the author of Matthew "jumped" from the toledot of Jacob in Genesis to the toledot of Jesus, thereby bypassing the two Josephs. He is not concerned with Joseph the son of Jacob, whether it be the Joseph of Genesis, or Joseph the husband of Mary. According to the author of Matthew, Jesus' toledot is the continuation of the toledot of Jacob, whether it be the Jacob of Genesis or the other Jacob who is the grandfather of Jesus.

The allusions, however, do not stop here. While reminding the reader of the toledot, or history, of Jacob, the narrator also reminds the reader of Jacob's dreams. However, it was not only Jacob who dreamt, but Joseph of Genesis, too. And now the other Joseph has a dream about the origin and name of the baby Mary is expecting. The angel informs Joseph "that the child Mary [is] carrying is "from a spirit that is holy' (Mt 1:20)" (Williams 2002:116), and that he should call the baby boy "Joshua", since "he is the one who is to save his people from their sins" (Mt 1:21).

The narrator reminds the reader of extra-ordinary birth narratives in the Old Testament. One has only to think of the narratives on the birth of Isaac (Gn 16:1; 17:17, 18:9-12), Samson (Jdg 13:1-3), and Samuel (1 Sm 1:4-5), in which the women were all barren. Mary is not barren, but she is too young, and has never been impregnated ${ }^{10}$. The narrator then adds some comments of his own (Mt 1:22-23):

Now all this took place to fulfil what the Lord had spoken through the prophet: Look! the virgin is with child and will give birth to a son whom they will call Immanuel, a name which means "God-is-with-us".

(New Jerusalem Bible 1985)

10 Smelik (2003:62) describes this with a beautiful play on words, which is difficult to render in English: "In het geval van Jezus is de moeder niet onvruchtbaar, maar onbevruchtbaar: zij is namelijk nog maagd". 
Isaiah, the eighth century Judean prophet, did not prophesy that Mary would conceive through an act of the Holy Spirit, or, as Williams (2002:116) translates, "a spirit that is holy". While addressing King Ahaz during the so-called Assyrian crisis (735-733 BCE), he encouraged Ahaz to trust the Lord and not to fear the onslaught of Razon, the Aramaean king, and Pekah, king of Israel. According to Isaiah, the two kings would not conquer and destroy Jerusalem. King Ahaz, however, did not believe Isaiah, but feared the onslaught of the two kings. Isaiah then proposed that King Ahaz should ask the Lord for a sign to prove that he was not lying. When the king rejected this proposal, Isaiah himself delivered a sign: "The young woman is with child and will give birth to a son whom she will call Immanuel"' (Is 7:14).

Old Testament scholars differ as to whom Isaiah was referring. Was it the king's wife, or the prophet's wife? Those who prefer the latter interpretation refer to Isaiah 8:1-4, where we read about a child who was born to the prophet. Those who disagree with this interpretation refer to the name of this child, Maher-Shalal-Hash-Baz (Is 8:3), claiming that he was not named Immanuel. They prefer to see the promised son as being the king's. Whichever interpretation is preferred, it is evident that the sign Isaiah gave King Ahaz could not have been that of the birth of Jesus. What sense would this have made for a king living in the eighth century BCE? Instead, the birth of a boy child was "intended to be a sign of divine protection for the city of Jerusalem" (Williams 2002:119).

Why, then, would the author of Matthew have quoted this verse from Isaiah? The quotation was probably introduced to affirm Jesus' status: "In a Jewish context, without prior knowledge of a virginal conception, Matthew's story might assert no more than that Jesus was holy in spite of the uncomfortable circumstances surrounding his conception and birth" (Williams 2002:120).

Matthew 1:18-25 makes the claim that Jesus was an important person with honour and status, but does not say that He was conceived by a virgin and was therefore uncontaminated by original sin. Jesus" importance lay in his being a "grandson" of the patriarch Jacob (Mt 1:16), there was a divine revelation concerning his birth (Mt 1:20-21), and his birth can be linked to a prophecy (Mt 1:23). 


\subsection{Luke 1:26-38}

It is common knowledge amongst New Testament scholars that Luke's birth narratives differ from those of Matthew. The first two chapters of Matthew's gospel are usually assigned to the so-called M-source, while the first two chapters of Luke are assigned to the so-called L-source. A comparison of the narratives reveals some interesting differences. In the Gospel of Matthew, an angel appears to Joseph in a dream and informs him on the state of affairs concerning Mary (Mt 1:20). In the Lukan passage, however, the angel Gabriel appears to Mary in broad daylight, giving her the news that she will conceive and give birth to a son, whom she should call "Joshua" (Lk 1:26-33). Mary is amazed, as she is still a "virgin" who has not slept with a man (Lk 1:34). The angel attributes the

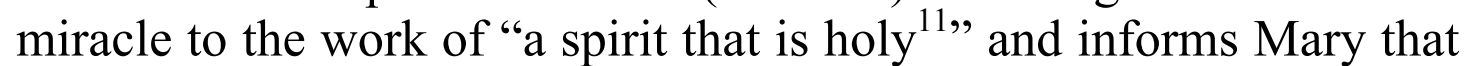
Elizabeth, her barren kinswoman, is already in her sixth month of pregnancy (Lk 1:35-37).

With the reference to Elizabeth, the narrator of this story is evidently recalling the pattern of Old Testament birth announcements. The Old Testament narratives usually concern an older woman who is barren or a woman who is struggling to conceive (Gn 16:1-2; 17:15-17; Jdg 13:1-5; 1 Sm 1:1-23). Mary, the young girl who has just entered puberty, stands in sharp contrast to the older, barren Elizabeth. As stated earlier, these types of stories were told to elevate the baby, bestowing on him the status of an important person. Only important people had extra-ordinary birth stories $^{12}$. However, the narrator wanted to emphasise something else. He wanted "to accentuate Jesus' superiority to John" (Klutz 2000:84). A comparison of the number of witnesses present at the birth scenes also gives evidence of this. While there is only one witness present to sing God's praise when John is born (Lk 1:67-

11 Here I am following Williams's proposal (2002:116, 117), and am not translating "the Holy Spirit" as if to indicate the third person of the Trinity.

12 "In de oudkerklijke belijdenissen is ook de belijdenis van Christus' geboorte deur de heilige Geest uit de maagd Maria - de leer van de maagdelijke geboorte - een onmisbaar criterium geweest voor het rechte geloof in zijn persoon. Historisch zal deze wonderlijke geboorte in het licht van de hellenistische kultuur als een eerbetoon aan Christus gezien moet worden. Elke godenzoon die iets voorstelde, held of keizer, heette op so 'n miraculeuze, maagdelijke manier verwekt te zijn" (Wiersinga 1992:71). 
80), a host of angels and shepherds are present, singing God's praise at the birth of Jesus ( $\operatorname{Lk} 2: 8-52)$.

Again, as seen in the birth narrative in Matthew's gospel, the emphasis does not fall on Jesus being born without sin and blemish. His extra-ordinary birth merely reflects his honour and status.

\subsection{The doctrine of the virgin birth $=$ human construct}

After Augustine argued the case for original sin commencing with the "fall", the birth narratives of Matthew and Luke became allimportant in Christianity. For Augustine, and for other theologians adhering to his ideas on original sin, the sinlessness of Jesus, which made salvation possible, depended on Mary's status as virgin (Spong 1992:217). A close reading of these narratives, reveals, however, that they are not concerned with the issue of original sin. As argued above, the authors of the birth narratives were concerned more with the honour and status of Jesus than with whether He was born without $\sin$ and blemish.

\section{CONCLUSION}

This article investigates whether the doctrines of original sin and the virgin birth can be classified as "divine revelation". I hope to have proven that they are mere human constructs. Both doctrines are classic examples of "eisogesis", "the skill of reading out of a text the interest we read into it" (Hoffmann 1993:241). Genesis 2-3, Psalm 51:7 and Romans 5:12-21 are not concerned with "original sin", while Matthew 1:18-25 and Luke 1:26-38 were not written to prove that Jesus was the eternal Son of God, or that the "virgin conception" saved him from carrying a "tainted" nature.

If these texts do not concern "original sin" and "salvation", we are confronted with the question: What should we do with the creeds and confessions of faith of the Christian tradition?

First, we should take leave of the grand narrative of a cosmic fall and redemption, because this meta-narrative is based on erroneous interpretations of biblical texts. Let us rather read and study the texts as having been written by human beings who lived in a world totally different from our own and who cherished another world-view. Let us also read and study the creeds and confessions in the context of the times in which they were conceived and written (Carroll 1991:84-85). This done, we may try to revive the message of Jesus of Nazareth to assess what it holds for our own times. I am 
convinced that his message and the message of all the Old Testament prophets and wisdom teachers can still be relevant to the world in which we live. However, an exclusive focus on the lives and survival of human beings can no longer be the cornerstone of all our theological reflections. The world in which we live is undergoing an ecological crisis and we need a theology that can engage it, one that can assist humans in changing their minds and behaviour. In the words of Jörg Zink (1997:58): “A theology which knows nothing but the lonely family history or family tragedy between God and humankind is a thing of the past."

\section{Consulted literature}

Bandstra, B 1995. Reading the Old Testament: An introduction to the Hebrew Bible. New York: Wadsworth.

Barr, J 1992. The Garden of Eden and the hope of immortality. London: SCM.

Bavinck, H 1932. Handleiding bij het onderwijs in den Christelijken Godsdienst. Kampen: Kok.

Benjamin, D C 1997. Stories of Adam and Eve in Sun, H T C \& Eades, K L (eds), Problems in biblical theology: Essays in honor of Rolf Knierim. Grand Rapids: Eerdmans, 38-58.

Bosman, H L 1983. Psalm 51:7 en erfsonde. NGTT 24, 264-271.

Brown, R E 1999. Virginal conception of Jesus, in Richardson, A \& Bowden, J (eds) A new dictionary of Christian theology. London: SCM, 597-598.

Carroll, R P 1991. Wolf in the sheepfold: The Bible as a problem for Christianity. London: SPCK.

Crenshaw, J L 2001. The Psalms: An introduction. Grand Rapids: Eerdmans.

Durand, J J F 1978. Die sonde. Pretoria: NG Kerkboekhandel (Wegwysers in die dogmatiek).

Du Toit, B 2000. God? Geloof in 'n postmoderne tyd. Bloemfontein: CLF.

Ehrman, B D 2008. The New Testament: A historical introduction to the early Christian writings. $4^{\text {th }}$ ed. New York: Oxford University Press.

Eloff, J N 1975. Die dilemma van die moderne Christenbioloog: Intreerede gelewer op 6 Mei 1975. Bloemfontein: UOVS.

Fokkelman, J P 2001. Reading Biblical poetry: An introductory guide. Louisville: Westminster John Knox.

-, 2002. The Psalms in form. Leiden: Deo (Tools for Biblical Study Series, 4).

Freeman, C 2003. The closing of the Western mind: The rise of faith and the fall of reason. London: Pimlico.

Gillingham, S E 1994. The poems and psalms of the Hebrew Bible. Oxford: Oxford University Press (The Oxford Bible Series). 
Hoffmann, R J 1993. Afterword, in Smith, M \& Hoffmann, R J (ed), What the Bible really says. San Francisco: HarperSanFrancisco, 239-243.

Käsemann, E 1974. An die Römer. Tübingen: Mohr (Handbuch zum Neuen Testament, 8a).

Klutz, T 2000. The value of being virginal: Mary and Anna in the Lukan infancy prologue, in Brooke, G J (ed), The birth of Jesus: Biblical and theological reflections. Edinburgh: T \& T Clark, 71-87.

Lampe, G W H 2003. Christian theology in the patristic period, in CunliffeJones, H (ed), A history of Christian doctrine. London: Continuum, 21180.

New Jerusalem Bible 1985. London: Darton, Longman \& Todd.

Ormerod, N 1992. Grace and disgrace: A theology of self-esteem, society, and history. Newtown (Australia): E J Dwyer.

Pelikan, J \& Hotchkiss, V 2003. Creeds and confessions of faith in the Christian tradition: Volume II, Part Four: Creeds and confessions of the Reformation era. New Haven: Yale University Press.

Primavesi, A 1991. From Apocalypse to Genesis: Ecology, feminism and Christianity. Minneapolis, MN: Augsburg Fortress.

Primavesi, A 2000. Theology and earth system science, in Parsons, S F (ed), Challenging women's orthodoxies in the context of faith. Hants: Ashgate, 21-34.

Revised English Bible 1989. Oxford: Oxford University Press.

Richardson, A \& Bowden, J (eds) 1999. A new dictionary of Christian theology. London: SCM.

Rosenberg, D \& Bloom, H 1990. The Book of J. New York: Weidenfeld.

Seybold, K 1997. Introducing the Psalms. Edinburgh: T\&T Clark.

Sisemore, T A 2004. From doctrine to practice: The influence of the doctrine of original sin on Puritan child rearing, in Ratcliff, D (ed), Children's spirituality: Christian perspectives, research, and applications. Eugene: Cascade Books, 219-232.

Slavenburg, J 1995. Valsheid in geschrifte: De gespleten pen van bijbelschrijvers. Zutphen: Walburg Pers.

Smelik, K A D 2003. De dood en de Bijbel. Heerenveen: Jongbloed.

Spangenberg, I J J 2003. Teologie op die markplein: 'n Post-apartheid teoloog dink na oor sy geloof en leefwêreld. Pretoria: C B Powell Bybelsentrum, UNISA.

Spong, J S 1992. Born of a woman: A bishop rethinks the birth of Jesus. New York: HarperCollins.

Theron, P F 2005. In sonde ontvang en gebore, sê wie? NGTT 46, 576-586.

Tucker, G M 1978. The creation and the fall: A reconsideration. Lexington Theological Quarterly 13, 113-124. 
Van Niekerk, A A 2005. Geloof sonder sekerhede: Besinning vir eietydse gelowiges. Wellington: Lux Verbi.BM.

Von Rad, G 1976. Genesis: A commentary. London: SCM (Old Testament Library).

Weber, G 1998. I believe I doubt: Notes on Christian experience. London: SCM.

Westermann, C 1972. Genesis 1-11. Darmstadt: WBG (Erträge der Forschung 7).

Wiersinga, H 1992. Geloven bij daglicht: verlies en toekomst van een traditie. Kampen: Kok.

Williams, R H 2002. An illustration of historical inquiry: Histories of Jesus and Matthew 1:1-25, in Blasi, A J, Duhaime, J \& Turcotte, P-A (eds), Handbook of early Christianity: Social science approaches. Walnut Creek: AltaMira, 105-123.

Zink, J 1997. Jörg Zink, in Moltmann, J (ed), How I have changed: Reflections on thirty years of theology. London: SCM, 55-64. 